\title{
THE IMPACT OF THE ACCOUNTABILITY ON ACCOUNTING DEVELOPMENT AS THE ESSENCE OF SUSTAINABILITY ACCOUNTING
}

\author{
Beata Zyznarska-Dworczak \\ Poznań University of Economics and Business, Poland \\ E-mail: b.zyznarska-dworczak@ue.poznan.pl
}

\begin{abstract}
Growing public awareness of the need for sustainability raises the need for business settlements in the line with the concept of accountability. This phenomenon contributes to the objective extension of information systems in enterprises, including accounting system. The aim of the study is to assess the impact of accountability on accounting development, showing thus the idea of sustainability accounting. This study investigates the significance of the accountability concept and was conducted, indicating in particular the types of this concept and the areas of its management in the company. Based on inductive and deductive reasoning, the thesis of the article has been proved, showing that the accountability concept directs the development of accounting towards sustainability accounting as one of the basic manifestations of corporate responsibility. The paper shows that a cascading of corporate accountability determines the areas in which accounting is crucial for the company management, like valuation of the results of the implementation of sustainable development principles, managerial control and sustainability reporting. This paper aims to promote the perception of the changes and prospects of the development of accounting towards sustainability accounting, presenting theoretical and practical implementations.
\end{abstract}

Keywords: accountability, accounting development, corporate responsibility, sustainable development, sustainability accounting.

\section{Introduction}

The concept of accountability means the obligation to account for the responsibility for the results of the impact on natural environment. The scope of corporate accountability is evolving along with the changes in the business environment. In recent years, the information expectations of stakeholders have been largely influenced by the concept of sustainable development. It results in that companies are expected to measure and report their financial and non-financial achievements, including socio-environmental results. Because of accountability companies need to adapt information systems for the settlement of corporate responsibility. Accounting is one of the instruments supporting settlement in the accountability concept.

Accounting has always been a settlement function however it has been concerned for the results of finance capital management. Nowadays, in the face of the growing importance of sustainability, it is necessary to extend the subject of accounting to financial and non-financial categories regarding social and environmental aspects. So, the problem of this research concerns the possibility of accounting to support corporate accountability, which requires not only measurement and reporting of financial capital management results, but also other capitals contributing to the value of the entity, including anthropogenic, natural and social capital. Therefore, this study serves to prove the thesis of this study that the accountability concept in a socially responsible enterprise requires the use of accounting, aimed at performing the set- 
Beata ZYZNARSKA-DWORCZAK. The impact of the accountability on accounting development as the essence of sustainability accounting

PROBLEMS

OF MANAGEMENT

IN THE $21^{\text {st }}$ CENTURY Vol. 14, No. 1, 2019

tlement of corporate responsibility. The aim of the study is to assess the impact of the accountability concept on business accounting and the role of accounting in the implementation of the accountability concept.

The research focuses on the development of accounting under the influence of the accountability concept, increasingly important in enterprises striving to implement the principles of sustainable development. The paper is structured as follows: after introduction the research methodology is presented, and then the third section provides the background for the research study and presents a literature review concerning the impact of accountability on accounting and sustainability accounting development, defined in the article "the idea of accountability vs accounting". This section presents the bibliometric analysis, conducted by the author to show the key trends in the field of accounting research, including those using the idea of accountability vs accounting, and those related to corporate sustainability. The fourth section, based on theoretical assumptions, gives an insight into issues regarding cascading of the accountability into the accounting tasks. This section presents the author's concept for the adoption of accounting as an instrument of accountability to form sustainability accounting. In this part, the author promotes the theoretical approach to the meaning of sustainability accounting. Based on practical assumptions, the risks associated with the implementation of these accounting tasks were also indicated, and at the same time it has been exposed the lack of the existing uniform conceptualization of sustainability accounting, and the existing framework only applies to reporting, far beyond the conceptual framework of accounting. Such a background is a source of discussion, presented in the further part of the paper. In the author's opinion, the future development of sustainability accounting will be influenced by the concept of accountability, what should guide research in the field of accounting and accounting practice.

\section{Research Methodology}

The study is of a theoretical and conceptual nature and appropriate research methods have been used. The paper relies on theoretical and methodological triangulation, using inductive and deductive reasoning as well as descriptive and comparative analysis. As a research background and the current recognition of the research problem was conducted the analysis of scientific literature. In order to organize and validate the research process, the bibliometric analysis was carried out based on the results from the database Web of Science and the database Web of Science Collection. The bibliometric tests allowed to indicate the trend in the research subject, including accountability vs accounting, and at the same time the growing importance of the "sustainability accounting". The bibliometric data covers accounting research conducted in 1945-2018 by the authors from all the world. The bibliometric data are collected in two local databases. One of the local databases contains 690 publications, covering research articles, conference papers and review papers relating to accountability vs accounting subject. It is a collection of the number of publications, their geographical origin, ranking of the publications by the author, and also WoS categories indicating the most popular field relating idea of accountability vs accounting. The bibliometric data enables to show citation index based on the Web of Science Core Collection. The other databases amount 249 papers relating to sustainability accounting and enable to analyse its future growth based on the number of publications and their citation. Conclusions from the analysis indicate the innovativeness of the issue undertaken in this paper and constitute the basis for further recognition of the importance of accounting in the accountability concept. The paper offers findings which are potentially useful for both theory and practice. 
Beata ZYZNARSKA-DWORCZAK. The impact of the accountability on accounting development as the essence of sustainability accounting

\section{Research Results}

Contemporary research on accounting and accountability results from practical reasons about the growing involvement of enterprises in the implementation of the principles of sustainable development (Elkington, 1994, 90-93; Haberl, et al., 2004, 199-203; Parker \& Chung, 2018, 993-994; Wood et al., 2015, 138-163; Zyznarska-Dworczak, 2019, 99-105). A wide range of research in this area is characterized by its interdisciplinary aspect, as well as the diversity of topics and methodologies in the analysis. Existing studies regarding this science area show that it has become an important field of research. Therefore, the author of this paper has applied a bibliometric method to determine state of the art of research perspectives of accounting against the background of the growing importance of accountability concepts in accounting, and in the second part - the importance of sustainability accounting. Due to its popular use in the academic world (Falagas, Pitsouni, Malietzis, \& Pappas, 2008), the Web of Science is selected as the key database for this study.

The first part of the bibliometric study is based on the data from 1945-2018. In accordance with the assumption adopted in the introduction, the bibliometric study covers research relating accounting area, based on research titled with the term accountability. In this way, a database has been created containing 690 publications, covering research articles, conference papers and review papers relating to research area of the paper. The number of publications held as source items in the Web of Science (Figure 1) and geographical origin (Figure 2). Due to the fact that from 1945 till 1973, there wasn 't recorded any result of "sustainability accounting", Figure 1 presents the results since 1974.

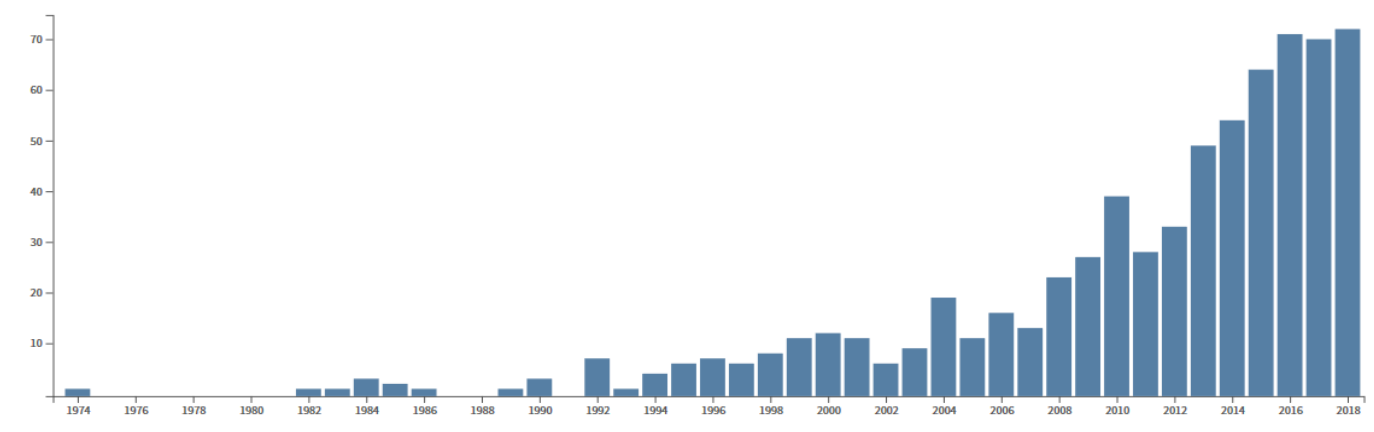

Figure 1. The trend in the number of articles included in Web of Science' database
relating to accounting vs accountability research.

Figure 1 illustrates that the number of publications relating to accounting vs accountability research is systematically growing, and the last decade has brought exceptionally high interest. The interest in such research is indicated in the following areas: business finance $(18.5 \%)$, public administration (12.7\%), management political science $(8.1 \%)$, education $(7.9 \%)$, educational research $(7.1 \%)$, business $(5.9 \%)$, law $(4.7 \%)$ and economics $(4.6 \%)$. Such a multidimensional aspect of accounting vs accountability research is the result, to a large extent, of the use of various theories in the accounting system research. Furthermore, the indicated interdisciplinary of the analysed research area is complemented by the popularity in different regions of the world (Figure 2). 
Beata ZYZNARSKA-DWORCZAK. The impact of the accountability on accounting development as the essence of sustainability accounting

OF MAI

ANAGEMENT IN THE $21^{\text {st }}$ CENTURY Vol. 14, No. 1, 2019
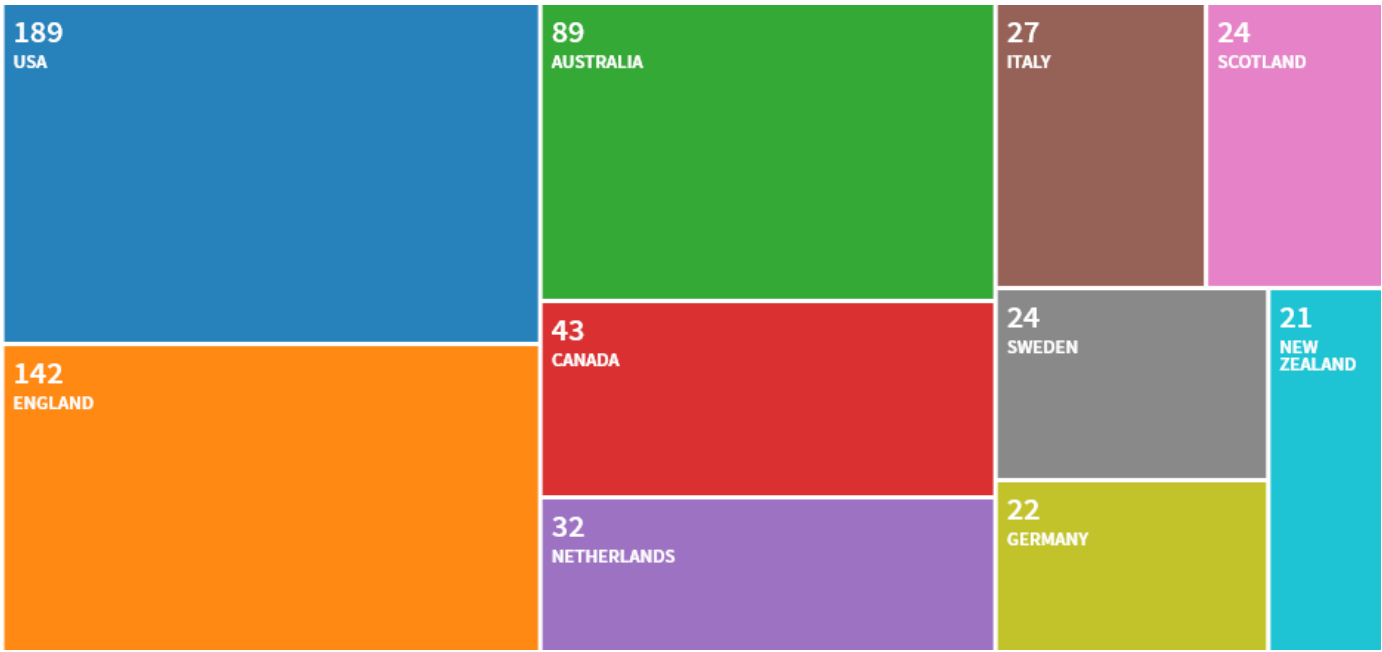

Figure 2. The number ranking of articles in Web of Science' database relating to the geographical origin of accounting vs accountability research in 1945-2017.

As the Figure 2 shows, the research on accountability vs accounting is the most popular in USA, England, Australia and Canada. Europe is showing much less interest, however, anticipating the growing importance of sustainability, further research can be expected in this region, too. The indicated growing interest based on the number of publications in the analysed area, can be complemented by an analysis of their citation. The overview of the citation statistics was carried out on the basis of data from the Web of Science Collection (Table 1, Figure 3).

Table 1. Overview of the citation statistics of articles in Web of Science' database in 1945-2018 - accountability vs accounting.

\begin{tabular}{ll}
\hline Citation Statistics & \\
\hline Results found & 690 \\
Sum of the times cited & 11034 \\
Citing articles & 9434 \\
Average citations per item & 15.99 \\
h-index & 47 \\
\hline
\end{tabular}

$\mathbf{S}$

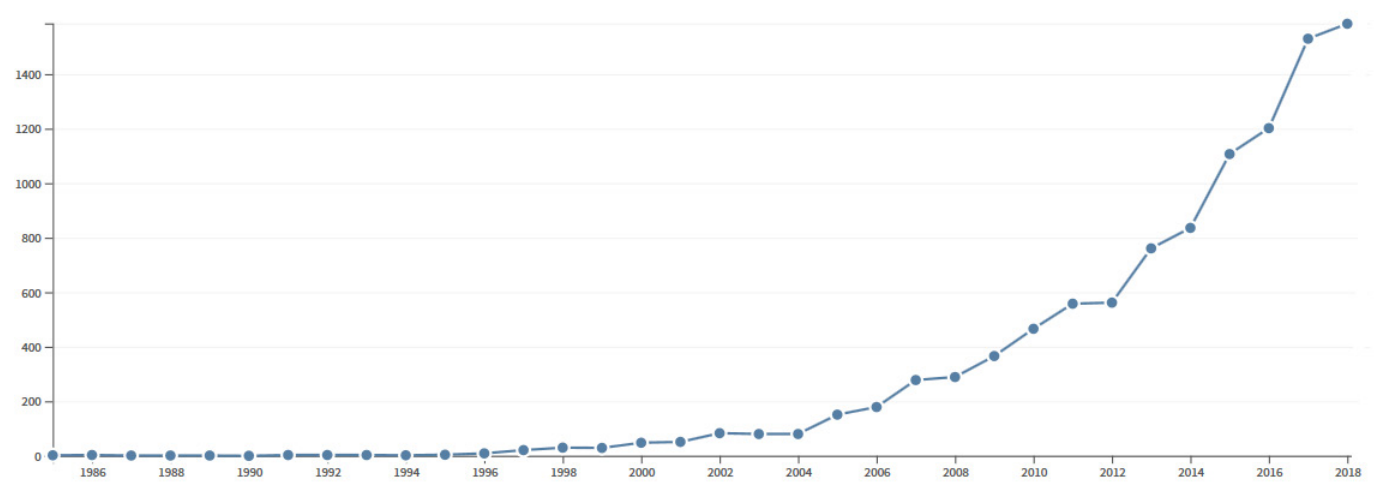

Figure 3. The trend in sum of times cited per year publication from accountability vs accounting area. 
Beata ZYZNARSKA-DWORCZAK. The impact of the accountability on accounting development as the essence of sustainability accounting

The presented data in figure 3 regarding the citation of publications (together over 11000) show a significant increase in interest in the last decade. The most cited items are the following:

1) Lerner \& Tetlock, 1999;

2) Grant \& Keohane, 2005;

3) Mulgan, 2000;

4) Laufer, 2003;

5) Roberts \& Scapens, 1985.

The indicated in this paper growing interest in the accountability vs accounting research contributes to the importance of research in the field of sustainability accounting. In order to present the growing trend of researchers' interest, a second bibliometric test was carried out, narrowing the database to publications containing the term of sustainability accounting in the title of the study. The study based on data from 1945-2018 shows that $85 \%$ of all publications were published in the last decade (2009-2018), and 55\% of publications have been published in the last 5 years (2014-2018). This proves the highest scientific interest, which is the result of changes in the corporate practice of accounting, more and more involved in accountability process in enterprises oriented on sustainable development.

As the WoS database shows, the meaning of sustainability accounting was considered in different research fields, like business finance (32.1\%), environmental sciences (18.4\%), environmental studies (16.5\%), green sustainable science technology (14\%) and management $(12 \%)$. This proves the interdisciplinary nature of the sustainability accounting concept. At the same time, it proves the need for cooperation of a wide range of specialists, which could help develop principles of accounting and accounting tools in the corporate accountability concept.

The high citation rates of publications dealing with sustainability accounting presents Table 2. The trend presented in Figure 4 shows a growing interest since 1994, in particular very fast growth is observed in the second decade of the 21 st century.

\section{Table 2. Overview of the citation statistics of articles in Web of Science' database in 1945-2018 - sustainability accounting.}

\begin{tabular}{ll}
\hline Citation Statistics & \\
\hline Results found & 249 \\
Sum of the Times Cited & 3058 \\
Citing articles & 2396 \\
Average Citations per Item & 12.28 \\
h-index & 27 \\
\hline
\end{tabular}

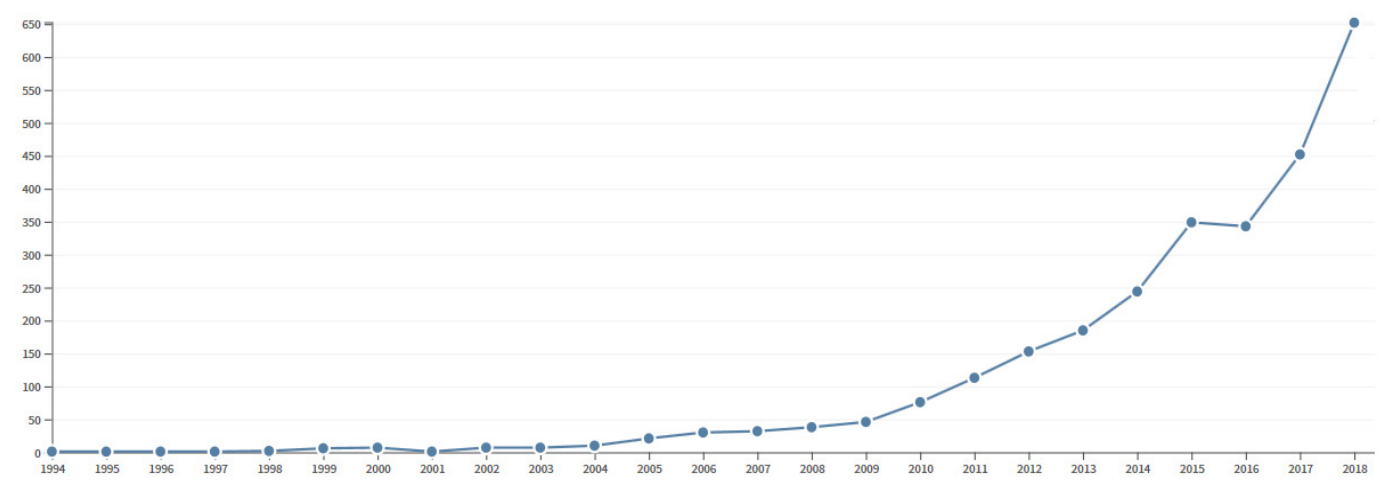

Figure 4. The trend in sum of times cited per year publication in 1994-2018 sustainability accountability. 
OF MANAGEMENT

IN THE $21^{\text {st }}$ CENTURY Vol. 14 , No. 1, 2019

78

The most cited publications relating to sustainability accounting are the following: Gray, 2010, 1992; Burritt and Schaltegger, 2010; Wood et al., 2015 and Haberl, et al. 2004. The analysis of the most cited paper supplemented with a detailed analysis of legal regulations in this area (Zyznarska-Dworczak, 2019, p. 84-93), however, does not allow for an explicit indication of the importance of sustainability accountability, nor its principles or role in accountability. The presented strong scientific interest in the development of sustainability accounting together with the growing involvement of enterprises in the implementation of the principles of sustainable development raises the need to clearly define the role of accounting in the accountability concept.

The accountability concept is variously defined, and the term "accountability" itself is used in various ways in the scientific literature. Analysis of its definitions indicates that it essentially means responsibility, ability, obligation, a specific legal status, form of interaction, and even technology (Bergsteiner \& Avery, 2010, p. 13; Bovens, 2014, p. 948-952; Feigenbaum, Jaggard \& Wright, 2011, p. 45; Gabbard 2000, p. 53; Gray et al., 1997, p. 4; Lerner \& Tetlock, 1999, p. 270). These approaches combine the purpose of this concept, which is to perform a settlement of responsibility for the impact on the natural environment of the company, local community, as well as humanity in general.

The accountability concept means a relatively simple relationship in which the accountability relationship exists between the actor (or accountor) and the one who is responsible to accountability forum or accountee. However, this relationship may contain many variables determining the functions of "principals" and "agents", determined on the basis of a formal or informal agreement, defining their various rights and obligations. In addition, the accountability concept may apply to power on a global, interstate, state, institution, large corporation, or business unit level, and at the same time may have an external and internal character, may be a social relation and a system of values.

With regard to the company and its relations with the environment (including internal and external stakeholders), using the term accountability requires clarification of the group of stakeholders to whom the information is dedicated and communicated, as well as the subject and scope of responsibility, and at the same time the method of its settlement. It is also important to set the rules for the gradual involvement of key stakeholders in setting the company's development directions. The importance of the concept of accountability is based on four basic pillars (Zyznarska-Dworczak, 2019, p. 73):

- a cause of accountability,

- a purpose of accountability,

- methods and targets of accountability

- directions of change in corporate accountability concept.

The accountability concept is gradually evolving, and its original assumptions are evolving along with the business environment and the expectations of corporate stakeholders. The key determinants of the accountability approach include factors such as difficulties in understanding accountability in the language of the agent and principal, as well as organizational problems related to multiple and competitive settlements, asymmetry of stakeholders' resources and power, and difficulties in balancing internal learning and innovation with external patterns and standards (Weisband \& Ebrahim, 2007, p. 13). The external dimension of the accountability concept, meaning the relationship between the "client" and the "agent", gradually complements the internal perspective of the company's responsibility to comply with the adopted standards and values. This division may result from formal mechanisms officially recorded in the company's strategy or under other agreements, as well as from informal mechanisms, integrated into the style and manner of conducting business, attitudes and values of individual employees. Thus, the accountability concept is determined not only from the financial perspective but also through the prism of the company's attitude and reaction, values and actions, and even in the light of global comparisons of social and environmental results throughout the chain (Parker \& Chung, 2018, p. 1011). Therefore, various information systems tools are needed to support 
Beata ZYZNARSKA-DWORCZAK. The impact of the accountability on accounting development as the essence of sustainability accounting

PROBLEMS

OF MANAGEMENT

IN THE $21^{\text {st }}$ CENTURY

Vol. 14, No. 1, 2019

managers in assessing the results of actions for sustainable development and settlement in the accountability concept. One of the forms of their identification is the process of accountability 79 cascading to various levels of business management. On this basis it is possible to distinguish the tasks that can be carried out by various departments, dedicated to various recipients and justified for various reasons or direction of settlement (see Table 3).

\section{Table 3. Corporate accountability cascading and accounting tasks.}

\begin{tabular}{|c|c|c|}
\hline $\begin{array}{l}\text { Accountability } \\
\text { cascading }\end{array}$ & Recipients & Direction of settlement \\
\hline Reporting & $\begin{array}{l}\text { - Upward to investors and owners and } \\
\text { oversight agencies; } \\
\text { - Downward (to a lesser degree) } \\
\text { to clients or members who read the reports }\end{array}$ & $\begin{array}{l}\text { - Legal requirement; } \\
\text { - Tax status; } \\
\text { - Funding requirement (external threat } \\
\text { of loss of funding, tax status or status of } \\
\text { socially responsible enterprise) }\end{array}$ \\
\hline $\begin{array}{l}\text { Performance } \\
\text { assessment } \\
\text { and evaluation } \\
\text { (tool) }\end{array}$ & $\begin{array}{l}\text { - Upward to funders and strategic investor; } \\
\text { - Significant potential for downward from an } \\
\text { enterprise to communities and investors and from } \\
\text { investors and owners to an enterprise }\end{array}$ & $\begin{array}{l}\text { - Funding requirement (external); } \\
\text { - Potential to become a learning tool } \\
\text { (internal) }\end{array}$ \\
\hline $\begin{array}{l}\text { Stakeholders } \\
\text { participation }\end{array}$ & $\begin{array}{l}\text { - Downward from an enterprise to clients and } \\
\text { communities; } \\
\text { - Internally to enterprises themselves; } \\
\text { - Significant potential for downward from investors } \\
\text { and owners to an enterprise. }\end{array}$ & $\begin{array}{l}\text { - Organizational values (internal); } \\
\text { - Funding requirement (external) }\end{array}$ \\
\hline Self-regulation & $\begin{array}{l}\text { - To enterprises themselves, as a sector; } \\
\text { - Potentially to clients, investors and donors }\end{array}$ & $\begin{array}{l}\text {-Erosion of public confidence due to } \\
\text { scandals and exaggeration of accom- } \\
\text { plishments (external loss of fund, internal } \\
\text { loss of reputation) }\end{array}$ \\
\hline $\begin{array}{l}\text { Managerial control } \\
\text { and audit }\end{array}$ & $\begin{array}{l}\text { - To enterprises themselves (by linking values to } \\
\text { strategy and performance); } \\
\text { - Downward and upward to stakeholders }\end{array}$ & $\begin{array}{l}\text { - Erosion of public confidence } \\
\text { (external); } \\
\text { - Valuation of social, environmental, and } \\
\text { ethical performance on par with } \\
\text { economic performance (internal) }\end{array}$ \\
\hline
\end{tabular}

Source: own elaboration based on Ebrahim, 2003, p. 825.

Each level of accountability cascading can be supported by accounting. However, at the same time each of the types of accountability (internal and external, downward and upward, vertical and horizontal) determines the method and tools for its settlement. Treating accounting as the basic information system of an enterprise, accounting can contribute to the determination of corporate accountability in the internal and external dimensions, ascending and descending, as well as in functional and strategic management. At the same time, it can significantly contribute to the development of individual levels of accountability cascading. The levels in which accounting can significantly support the accountability concept include primarily:

- reporting:

- measurement of results and their evaluation

- control and audit.

Today, business reporting, including in particular increasingly popular reporting on sustainable development, can be seen as an expression of greater accountability (Fijałkowska \& Zyznarska, 2018, p. 47). It serves to implement the information needs of external and internal 
Beata ZYZNARSKA-DWORCZAK. The impact of the accountability on accounting development as the essence of sustainability accounting

PROBLEMS

OF MANAGEMENT

IN THE $21^{\text {st }}$ CENTURY Vol. 14, No. 1, 2019

stakeholders, not only resulting from legal requirements, but also optionally presenting the results of the entities' achievements. Gradual substantive expansion of accounting in terms of measurement and reporting is observed, both in accounting science and practice. According to Gray (2002) sustainability accounting takes a wide variety of forms and appears under various labels and is used as a generic term for convenience to cover all forms of 'accounts which go beyond the economic' and for all the different labels under which it appears - social accounting, environmental accounting, social responsibility accounting, social audits, corporate social reporting, employee and employment reporting, stakeholder dialogue reporting as well as environmental accounting and reporting (Gray, 2002, p. 687-700). These tasks, which are hidden under the name sustainability accounting, confirm other researchers. For example, Unerman, Bebbington and O'Dwyer (2007) stated that, just as conventional management and financial accounting have provided tools in the management, planning, control and accountability of the economic aspects of an enterprise, broader techniques of sustainability accounting and accountability have the potential to be tools in the management, planning, control and accountability of organizations for their social and environmental impacts. Burritt and Schaltegger (2010) perceived corporate sustainability accounting as a set of tools that provide help for managers dealing with different decisions. They praise the managerial path of sustainability accounting, negating other tasks and noticing in them the risks for accounting development and its significance for sustainability.

Thus, accounting can be considered as an instrument of accountability concept. The author of this paper suggests treating sustainability accounting in two ways. First of all, it is an integrated system of financial measurement of economic, social and environmental aspects, enabling communication of information and disclosures about the company's achievements for sustainable development to key internal and external stakeholders. Second, accounting is a tool for strategic management of a sustainable enterprise, which, through the measurement of results, serves to assess the degree of implementation of sustainable development principles as the basis for settling the economic, social and environmental responsibility of the enterprise, and to communicate results (Zyznarska-Dworczak, 2019, p. 245-246):

- reporting on achievements towards external stakeholders,

- multidimensional presentation of the results of the implementation of operational and strategic activities supporting the management of the enterprise.

However, it is worth adding that despite the indicated trends, current accounting standards are not able to keep up with the dynamic and diverse economic reality. Furthermore, accounting development towards sustainability accounting raises a number of risks for accounting system, in particular referring to accounting as a source of credibility of non-accounting categories. These risks result from the fact that in the current business practice and accounting science, there is no uniform accounting policy used for the settlement of an enterprise with its economic, social and environmental responsibility. It is very dangerous for the accounting perception as a guardian of credibility when it is identified with unethical communication practices like whitewashing, bluewashing or greenwashing (more f.e. Lau, et al. 2017, p. 48-61; Laufer, 2003, p. 253-261), as well as the use of information from the accounting system for narrative purposes with the intended context of the author of the publication. The speed of changes in practical activities and scientific research in the field of sustainable development has not yet allowed to clearly indicate the role of accounting in this area. That is why the continuing challenge for accounting is to create "the opening of new spaces, new settlements, and not just reacting to old tasks", to explain the change in the practice of sustainable development (Gray, 2002, p. 698). It requires support for the process of measuring results, both for the needs of internal and external settlement, taking into account the operational and strategic levels of incorporation of accountability concept into the enterprise. 
Corporate social responsibility is becoming an increasingly popular area of activity of companies which are interested in not only the managers or owners, but also customers, suppliers, NGOs, administrative and other stakeholder groups (Drewniak, 2015, p. 62). It requires, above all, the incorporation of the accountability concept into business. The external dimension of the accountability concept, which means the relation between the "client" and the "agent", complements the perspective of the internal concept that means the company is responsible to itself for compliance with the accepted norms and values. The internal dimension of accountability requires managers to enforce the responsibility of decision-makers for economic rationality taking into account social and environmental rationality, and at the same time for the compliance of actions with the ethics principles.

This approach contributes greatly to the even more comprehensive management of a modern enterprise, with complex phenomena of uncertainty, non-linearity, self-organization, turbulence, and unpredictability. The existing and applied systems of decision-making are often inadequate to the new challenges encountered by enterprises (Gorzeń-Mitka, 2015, p.4), and the changes brought by the accountability concept introduce even greater dissonance. It is more important to adapt information systems, including accounting, to support managerial decisions.

Accounting can support internal and external dimensions of accountability - from reporting on achievements for sustainable development and its attestation to managerial control of financial and non-financial aspects. Enforcing these tasks implies accounting development aimed at:

- building the company's responsibility for impact on the environment,

- calculating and controlling the company's activities for sustainable development,

- settlement of company responsibility in the accountability concept,

- taking into account the social and environmental needs of stakeholders resulting from the impact of the company and the impact of the company's achievements in this area on the final outcome of political, cultural, social and institutional relationships.

The problem of this research, requiring in-depth research and scientific discussion, is to assess whether accounting will manage to face the challenge of supporting corporate accountability. Measuring achievements, documenting and verifiability, and then communicating requires the preparation of multidimensional information to assess the purposefulness of the company's operations. Necessary for this purpose is the extension of the subject of accounting, the development of uniform principles, as well as the development of tools and IT systems supporting multidimensional measurement and communication to internal and external stakeholders. However, many categories related to sustainable development are non-measurable in existing accounting opportunities, there are a number of risks with the loss of accounting credibility if it will present the non-verifiable categories. The growing interest in accounting presented in the article will suggest that all needed solutions will be developed, however currently accounting is in the development phase, accelerated by the growing importance of the accountability concept towards the need for sustainable development. In the author's opinion, both, normative and positive research is still needed, directing accounting to fulfil the function in the accountability concept. An attempt to determine the role and tasks of accounting as an accountability tool was made in the further part of the article.

\section{Conclusions}

The evolution of accounting, recognized in practice and science, results mainly from information needs of external and internal stakeholders. The growing importance of sustainable development implicates that stakeholders' expectations concern in particular the settlement of the economic, environmental and social corporate responsibility under the accountability concept. Due to accountability approach accounting, although concentrated mainly so far on 
Beata ZYZNARSKA-DWORCZAK. The impact of the accountability on accounting development as the essence of sustainability accounting

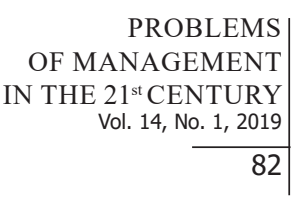

82

the results of financial capital management, is expected to help assess results of management of other capitals contributing to the value of the entity.

Sustainability accounting, as the study shows, may be an instrument of the accountability concept. It may significantly support particular levels resulting from accountability cascading, in terms of reporting, measuring results and their evaluation, stakeholder participation, self-regulation and control. Indeed, accounting system may assist the settlement of corporate responsibility, especially in its reporting dimension, as well as managerial control and audit of environmental and social aspects. However, as it was shown in this paper, despite many scientific studies, accounting still did not develop uniform principles and rules that would systematically support sustainability settlement in companies. Sustainability accounting is still in the development phase, which requires in-depth normative and positive research.

The implications of this study concern business practice and science. The practical implications of the presented approach to accounting tasks arise from its utilitarian character and are connected with the need to extend the subject of accounting. This approach determines changes in the basic tasks of accounting, including regarding valuation, reporting and management of corporate achievements for sustainable development. At the same time, this study shows the gap in accounting science, resulting from the fact that there is a lack of the generally valid conceptualization of accounting, like of financial accounting. The presented approach may be an incentive to conduct further research on the development of sustainability accounting.

\section{References}

Bergsteiner, H., \& Avery, G. C. (2010). A theoretical responsibility and accountability framework for CSR and global responsibility. Journal of Global Responsibility, 1(1), 8-33.

Bovens, M. (2014). Two concepts of accountability: Accountability as a virtue and as a mechanism. In: Curtin D., Mair P., Papadopoulos Y. (Eds.). Accountability and European Governance (pp. 28-49). London: Routledge.

Burritt, R. L., \& Schaltegger, S. (2010). Sustainability accounting and reporting: Fad or trend? Accounting, Auditing \& Accountability Journal, 23(7), 829-846.

Drewniak, R. (2015). Conditions of cooperation between companies and NGOs in the field of Corporate Social Responsibility activities: the Polish cases. Problems of Management in the 21st Century, $10(2), 62-76$

Ebrahim, A. (2003). Accountability in practice: Mechanisms for NGOs. World development, 31(5), 813829.

Elkington, J. (1994). Towards the sustainable corporation: Win-win-win business strategies for sustainable development. California Management Review, 36(2), 90-100.

Falagas, M. E., Pitsouni, E. I., Malietzis, G. A., \& Pappas, G. (2008). Comparison of PubMed, Scopus, Web of Science, and Google scholar: Strengths and weaknesses. The FASEB Journal, 22(2), 338342.

Feigenbaum, J., Jaggard, A. D., \& Wright, R. N. (2011). Towards a formal model of accountability. In: Proceedings of the 2011 New security paradigms workshop (pp. 45-56). New York: ACM.

Fijałkowska, J., \& Zyznarska-Dworczak, B. (2018). Sustainability reporting of Polish banks - A step towards greater accountability. Entrepreneurship and Management, 19(1), 47-61.

Gabbard, D. (2000). Accountability. In: Gabbard D. (Ed.), Knowledge and power in the global economy: Politics and the rhetoric of school reform (pp. 191-198). New York: Lawrence Erlbaum Associates.

Gorzeń-Mitka I., 2015. Complexity in management: Opportunity or threat? Problems of Management in the 21st Century, 10(1), 4-5.

Grant, R. W., \& Keohane, R. O. (2005). Accountability and abuses of power in world politics. American Political Science Review, 99(1), 29-43.

Gray, R. (1992). Accounting and environmentalism: An exploration of the challenge of gently accounting for accountability, transparency and sustainability. Accounting, Organizations and Society, 17(5), $399-425$

Gray, R. (2002). The social accounting project and Accounting Organizations and Society Privileging engagement, imaginings, new accountings and pragmatism over critique? Accounting, Organizations and Society, 27(7), 687-708. 
Beata ZYZNARSKA-DWORCZAK. The impact of the accountability on accounting development as the essence of sustainability accounting

Gray, R. (2010). Is accounting for sustainability actually accounting for sustainability... and how would we know? An exploration of narratives of organisations and the planet. Accounting, Organizations and Society, 35(1), 47-62.

Gray, R., Dey, C., Owen, D., Evans, R. \& Zadek, S. (1997). Struggling with the praxis of social accounting: Stakeholders, accountability, audits and procedures. Accounting, Auditing \& Accountability Journal, 10(3), 325-364.

Haberl, H., Fischer-Kowalski, M., Krausmann, F., Weisz, H., \& Winiwarter, V. (2004). Progress towards sustainability? What the conceptual framework of material and energy flow accounting (MEFA) can offer. Land Use Policy, 21(3), 199-213.

Herremans, I. M., \& Nazari, J. A. (2016). Sustainability reporting driving forces and management control systems. Journal of Management Accounting Research, 28(2), 103-124.

Lau, C. L., Fisher, C. D., Hulpke, J. F., Kelly, W. A., \& Taylor, S. (2017). United nations global compact: The unmet promise of the UNGC. Social Responsibility Journal, 13(1), 48-61.

Laufer, W. S. (2003). Social accountability and corporate greenwashing. Journal of Business Ethics, 43(3), 253-261.

Lerner, J. S., \& Tetlock, P. E. (1999). Accounting for the effects of accountability. Psychological Bulletin, $125(2), 255$.

Mathison, S., \& Ross, E. W. (2002). The hegemony of accountability in schools and universities. WorkPlace: A Journal for Academic Labor, 9, 88-102.

Mulgan, R. (2000). 'Accountability': An ever-expanding concept? Public Administration, 78(3), 555573.

Laufer, W. S. (2003). Social accountability and corporate greenwashing. Journal of Business Ethics, 43(3), 253-261.

Parker, L. D., \& Chung, L. H. (2018). Structuring social and environmental management control and accountability: Behind the hotel doors. Accounting, Auditing \& Accountability Journal, 31(3), 993-1023.

Perks, R. W. (1993). Accounting and society (Vol. 215). London: Chapman \& Hall.

Roberts, J., \& Scapens, R. (1985). Accounting systems and systems of accountability - understanding accounting practices in their organisational contexts. Accounting, Organizations and Society, 10(4), 443-456.

Unerman, J., Bebbington, J., \& O’Dwyer, B. (2007). Introduction to sustainability accounting and accountability, In: J. Unerman, J. Bebbington \& B. O’Dwyer (Eds.), Sustainability accounting and accountability. London and New York: Routledge.

Weisband, E., \& Ebrahim, A. (2007). Introduction: Forging global accountabilities. In: Ebrahi A. \& Weisband E. (Ed.). Global accountabilities: Participation, pluralism and public ethics (pp. 1-24). UK: Cambridge University Press.

Wood, R., Stadler, K., Bulavskaya, T., Lutter, S., Giljum, S., De Koning, A., ... \& Simas, M. (2015). Global sustainability accounting - developing EXIOBASE for multi-regional footprint analysis. Sustainability, 7(1), 138-163.

Zyznarska-Dworczak, B. (2018). The development perspectives of sustainable management accounting in Central and Eastern European Countries. Sustainability, 10(5), 1445.

Zyznarska-Dworczak, B. (2019). Rachunkowość zrównoważona w ujęciu kognitywno-teoretycznym [Balanced accounting in cognitive-theoretical terms]. Poznań: Wydawnictwo Uniwersytetu Ekonomicznego w Poznaniu.

Received: April 30, 2019

Accepted: June 27, 2019

Beata Zyznarska-Dworczak

PhD, Assistant Professor, Department of Accounting, Poznań University of Economicsand Business, Poland, al. Niepodległości 10,61-875Poznań, Poland. E-mail: b.zyznarska-dworczak@ue.poznan.pl Website: https://orcid.org/0000-0002-0827-2583 